\title{
Collaborative modeling of the impact of obesity on race-specific breast cancer incidence and mortality
}

\author{
Yaojen Chang - Clyde B. Schechter - Nicolien T. van Ravesteyn • \\ Aimee M. Near - Eveline A. M. Heijnsdijk - Lucile Adams-Campbell • \\ David Levy • Harry J. de Koning • Jeanne S. Mandelblatt
}

Received: 18 September 2012/ Accepted: 20 September 2012/Published online: 27 October 2012

(C) The Author(s) 2012. This article is published with open access at Springerlink.com

\begin{abstract}
Obesity affects multiple points along the breast cancer control continuum from prevention to screening and treatment, often in opposing directions. Obesity is also more prevalent in Blacks than Whites at most ages so it might contribute to observed racial disparities in mortality. We use two established simulation models from the Cancer Intervention and Surveillance Modeling Network (CISNET) to evaluate the impact of obesity on race-specific breast cancer outcomes. The models use common national data to inform parameters for the multiple US birth cohorts of Black and White women, including age- and race-specific incidence, competing mortality, mammography characteristics, and treatment effectiveness. Parameters are modified by obesity (BMI of $\geq 30 \mathrm{~kg} / \mathrm{m}^{2}$ ) in conjunction with its age-, race-, cohort- and time-period-specific prevalence. We measure age-standardized breast cancer incidence and mortality and cases and deaths attributable to obesity. Obesity is more prevalent among Blacks than Whites until age 74; after age 74 it is more prevalent in Whites. The models estimate that the fraction of the US
\end{abstract}

Y. Chang · A. M. Near · L. Adams-Campbell - D. Levy ·

J. S. Mandelblatt ( $\square)$

Cancer Prevention and Control Program,

Department of Oncology, Lombardi Comprehensive Cancer

Center, Georgetown University Medical Center, 3300

Whitehaven Street, Suite 4100, Washington, DC 20007, USA

e-mail: mandelbj@georgetown.edu

C. B. Schechter

Departments of Family \& Social Medicine and Epidemiology and Population Health, Albert Einstein College of Medicine, Bronx, NY, USA

N. T. van Ravesteyn - E. A. M. Heijnsdijk - H. J. de Koning Department of Public Health, Erasmus MC, Rotterdam,

The Netherlands breast cancer cases attributable to obesity is 3.9-4.5\% (range across models) for Whites and $2.5-3.6 \%$ for Blacks. Given the protective effects of obesity on risk among women $<50$ years, elimination of obesity in this age group could increase cases for both the races, but decrease cases for women $\geq 50$ years. Overall, obesity accounts for $4.4-9.2 \%$ and $3.1-8.4 \%$ of the total number of breast cancer deaths in Whites and Blacks, respectively, across models. However, variations in obesity prevalence have no net effect on race disparities in breast cancer mortality because of the opposing effects of age on risk and patterns of age- and race-specific prevalence. Despite its modest impact on breast cancer control and race disparities, obesity remains one of the few known modifiable risks for cancer and other diseases, underlining its relevance as a public health target.

Keywords Simulation modeling - Breast cancer . Disparities · Obesity

\section{Introduction}

The burden of breast cancer has been decreasing over time $[1,2]$, but mortality gaps between Black and White women have been persistent [3]. The higher mortality rate for Black women is particularly striking now, given virtually equivalent screening rates and lower incidence than White women $[4,5]$. Racial differences in breast cancer outcome are cast on a backdrop of an obesity epidemic that disproportionately affects Black women. Currently, more than $50 \%$ of Black women are obese (defined as a BMI of $\geq 30 \mathrm{~kg} / \mathrm{m}^{2}$ ), compared to $32.0 \%$ of White women $[6,7]$ but there are exceptions to this overall trend, with Whites having higher rates of obesity after age 74 [6-8]. 
Obesity exerts numerous, often opposing effects on the chain of events leading to possible death from breast cancer. It increases breast cancer incidence in post-menopausal women, but reduces risk in pre-menopausal women [9-13]. Obesity also leads to more favorable tumor types [13, 14], greater sensitivity of detection [15], but more advanced stage [16-18], lower treatment effectiveness [19, 20], and greater competing mortality [8, 21, 22]. The Institute of Medicine recently noted that simulation modeling is particularly useful for evaluating the net impact of a factor such as obesity that affects multiple points in a disease process differentially [23]. Modeling is also helpful in evaluating the role obesity plays in racial disparities by providing a "virtual laboratory" to evaluate the impact of varying conditions that cannot be readily tested in the population, such as the net impact of reductions in obesity prevalence on breast cancer rates [24, 25].

In this article, we use two established, independent simulation models to evaluate how obesity affects breast cancer incidence and mortality in US Black and White women. We also investigate how much of the disparity in breast cancer mortality is due to the differential prevalence of obesity. Our results are intended to inform debates about effective strategies to reduce racial gaps in breast cancer mortality and reduce the burden of breast cancer for all women.

\section{Methods}

The two models, called MISCAN and SPECTRUM, were developed within the Cancer Intervention and Surveillance Modeling Network (CISNET) [26] and were exempt from institutional review board approval. The models have been described in detail elsewhere [2, 24, 27, 28]. Briefly, both are discrete event-driven, continuous-time state transition models that project US breast cancer population trends in the absence of screening or treatment and then overlay screening and adjuvant treatment diffusion over time. Breast cancer is depicted as having a preclinical screendetectable period (sojourn time) and a clinical detection point. On the basis of mammography sensitivity (or thresholds of tumor size detection), screening identifies disease in the preclinical screen-detectable period and results in the identification of earlier stage or smaller, more curable tumors than might occur via clinical detection, resulting in reduced breast cancer mortality. Age at diagnosis, estrogen-receptor (ER) and human epidermal growth factor-2 (HER2) status and tumor size- or stage-specific treatment have independent effects on probability of a cure (or survival). Women can die of breast cancer or of other causes.

MISCAN portrays tumor growth, where tumors can be detected once they are larger than a detection threshold and cured if the diameter at detection is below a fatal threshold. In SPECTRUM, tumors progress through stages, with screening effects due to age- and stage-shifts and treatment reducing the hazard of death. In both, ductal carcinoma in situ (DCIS) can regress, remain and be diagnosed, or progress to invasive cancer. In previous collaborations, the models generated similar estimates of incidence and mortality [2, 24, 29].

\section{Model parameters}

Using data from clinical trials and epidemiological studies, the models employ a common set of parameters to portray race-specific effects and then superimpose the impact of obesity on each parameter (Table 1). Each includes modelspecific parameters to represent sojourn, lead, and dwell time within stages or tumor diameter growth times and stage distribution or tumor size [2, 24, 27, 28].

\section{Demographic data and obesity}

The population consists of cohorts of US Black and White women born between 1890 and 2010 [30]. We start in 1890 to project prevalent cancers in the 1970s. Women are assigned to being obese or non-obese based on rates observed for their age, birth cohort, race, and the calendar year using prevalence data from the National Health and Nutrition Examination Survey I (1970-1975), II (1976-1980), III (1988-1994), and 1999-2004 [8]. These data are extrapolated to 2009-2010 using the most recent NHANES data [7]. We do not allow transitions from obese to non-obese (or back again to obese) because there are insufficient data on how such transitions would affect all the model parameters.

\section{Breast cancer incidence}

Breast cancer incidence in the absence of screening is based on an age-period-cohort (APC) model [31]. We extrapolate forward based on rates in 2000 so do not capture the more recent decrease in incidence [32]. The APC model is adapted for Black women using an age-specific relative risk (RR) based on Black versus White incidence [24]. Based on a synthesis of studies, obesity is modeled as increasing breast cancer incidence in post-menopausal women by a RR of 1.25 and decreasing rates in premenopausal women by a RR of 0.60 [9-11, 33].

\section{Mammography}

The dissemination of mammography is depicted based on the age of receipt of the first mammography and the interval between subsequent mammograms using data from the Breast Cancer Surveillance Consortium (BCSC) 
Table 1 Common model input parameters

\begin{tabular}{|c|c|c|c|c|}
\hline Parameter & Race-specific & Source & Obesity-specific & Source \\
\hline Births & Birth cohorts born from 1890 to 2000 by race & {$[30]$} & - & \\
\hline Obesity prevalence & Race, cohort and year-specific & {$[74,75]$} & - & {$[74,75]$} \\
\hline Incidence & $\begin{array}{l}\text { Age-period cohort model with age-specific } \\
\text { relative risk of Black versus White incidence }\end{array}$ & {$[24,31]$} & $\begin{array}{l}\text { For obese (BMI } \geq 30) \text { vs. non-obese: } \\
<50 \text { : RR } 0.6(95 \% \text { CI } 0.4-1.0) \\
50+: \text { RR } 1.25 \text { (95\% CI } 1.1-2.0) \\
\text { Assume obesity effect equal by race }\end{array}$ & {$[9-11,33]$} \\
\hline Mammography use & $\begin{array}{l}\text { Dissemination based on age- and race-specific } \\
\text { rates for first and subsequent exams and } \\
\text { intervals between screenings. }\end{array}$ & [34-37] & $\begin{array}{l}\text { Assume obesity does not affect rate of } \\
\text { screening }\end{array}$ & [38] \\
\hline $\begin{array}{l}\text { Mammography } \\
\text { sensitivity }\end{array}$ & $\begin{array}{l}\text { Age-specific rates for first and subsequent } \\
\text { screening exams; equal by race based on } \\
\text { unpublished BCSC data. }\end{array}$ & {$[39]$} & BMI-specific & $\begin{array}{l}\text { Unpub. } \\
\text { BCSC } \\
\text { data }\end{array}$ \\
\hline Sojourn time & $\begin{array}{l}2 \text { years if age } \leq 40 \\
2+0.2(\text { age }-40) \text { if age } 40-49 \\
4 \text { if age } \geq 50 \\
\text { Assume equal by race }\end{array}$ & [76] & $\begin{array}{l}\text { Assume sojourn time is equal across } \\
\text { BMI categories. }\end{array}$ & - \\
\hline ER/HER2 & $\begin{array}{l}\text { Regression model using NCCN data } \\
\text { from 2,646 women }\end{array}$ & {$[24]$} & $\begin{array}{l}\text { Risk of ER+ breast cancer, obese vs. } \\
\text { non-obese: } \\
<50 \text { : RR } 0.86 \text { (95\% CI } 0.77-0.95) \\
\text { 50+: RR } 1.78 \text { (95\% CI 1.50-2.11) } \\
\text { Assume no effect HER2 }\end{array}$ & {$[14]$} \\
\hline Mean stage dwell time & $\begin{array}{l}\text { DCIS } 5 \text { years } \\
\text { Stage } 12.60 \text { years } \\
\text { Stage } 2 \mathrm{a} 1.26 \text { years } \\
\text { Stage } 2 \mathrm{~b} 1.27 \text { years } \\
\text { Stage } 34.08 \text { years } \\
\text { Stage } 4 \text { N/A } \\
\text { Assume equal by race }\end{array}$ & {$[27,28]$} & Assume no effect of obesity & - \\
\hline \multicolumn{5}{|l|}{ Stage distribution } \\
\hline $\begin{array}{l}\text { Unscreened } \\
\text { Screened }\end{array}$ & $\begin{array}{l}\text { Varies by age, race and year } \\
\text { Varies by age and race }\end{array}$ & $\begin{array}{l}\text { [40], Unpub. } \\
\text { BCSC data }\end{array}$ & BMI-specific stage & $\begin{array}{l}\text { Unpub. } \\
\text { BCSC } \\
\text { data }\end{array}$ \\
\hline Survival without $\mathrm{Rx}$ & Survival by race from SEER in 1975-1979 & {$[40]$} & $\begin{array}{l}\text { Assume no effect of obesity on breast } \\
\text { cancer-specific survival }\end{array}$ & - \\
\hline Treatment dissemination & $\begin{array}{c}\text { Blacks } 22 \% \text { less likely to receive chemo; } \\
10 \% \text { (<age } 50 \text { ) to } 15 \% \text { (age } 50+\text { ) less } \\
\text { likely to get hormonal } \mathrm{Rx} \text { than Whites }\end{array}$ & {$[43,44]$} & $\begin{array}{l}\text { Obesity has no effect on treatment } \\
\text { dissemination }\end{array}$ & {$[52]$} \\
\hline Treatment effectiveness & $\begin{array}{l}\text { Meta-analyses of randomized trial results; } \\
\text { assume treatment effectiveness is equal by } \\
\text { race }\end{array}$ & {$[47-51]$} & $\begin{array}{l}\text { Reduce hazard ratios by } 0.55 \text { for obese } \\
\text { ER-negative women who receive dose } \\
\text { reductions; } 30 \% \text { of obese women have } \\
\text { a dose-reduction }\end{array}$ & {$[19,20]$} \\
\hline Other cause mortality & $\begin{array}{l}\text { Age-, race-, and cohort-specific all-cause } \\
\text { mortality rates by year }\end{array}$ & {$[54,55]$} & NHANES-linked mortality database & {$[8]$} \\
\hline
\end{tabular}

$[34,35]$. This parameter was extended using BCSC data to include different screening rates and intervals for Blacks and Whites [36, 37]. Mammography use does not generally vary by BMI (except for the extremes for underweight and extremely obese) [38], so we assume obesity has no effect on mammography dissemination.

Sensitivity and specificity of mammographic screening for DCIS and invasive cancer were estimated by age group (under and over 50), screening round (first or subsequent), and obesity group using unpublished BCSC data [39]. There was no difference in test characteristics by race.

\section{Stage distribution}

The tumor stage distribution in the absence of screening for Black and White women was estimated from the SEER 
Fig. 1 Model predicted ageadjusted breast cancer incidence and mortality by model, race and calendar year versus observed SEER rates for US women age $25+$
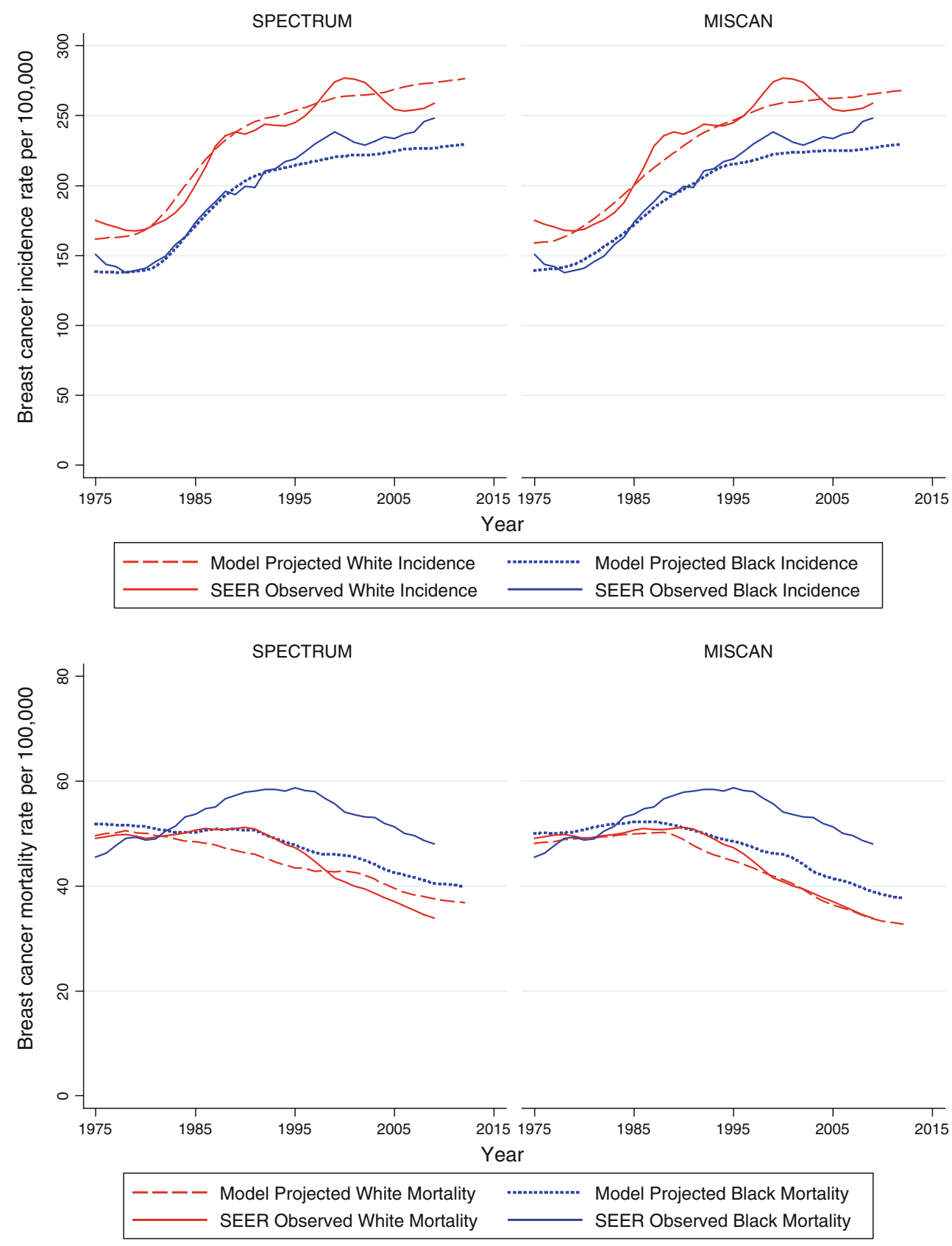

data in 1975-1979 before widespread use of mammography [40] and updated over time using race-specific BCSC data for unscreened (clinically detected) women. Stage distributions among screened women were estimated using race-specific BCSC data from 1996 to 2007 by screening intervals and first versus subsequent screen detection (unpublished data).

Obesity is associated with more advanced tumors at diagnosis overall $[16,41]$ and in Blacks and Whites [17, 18], even after accounting for mammography use [15]. Therefore, we used BCSC data stratified by BMI and age group to represent the impact of obesity on stage for unscreened and screened women of both races.

\section{Tumor biomarkers}

We estimated the joint distribution of ER and HER2 status by age, year, stage, and race using data from 1997 to 2005 [24, 42]. As obesity affects the rate of ER+ tumors differentially by menopausal status [14], we applied RRs of 0.86 and 1.78 to the probability of having ER+ cancer among obese women $<50$ and $50+$, respectively. We assumed that 

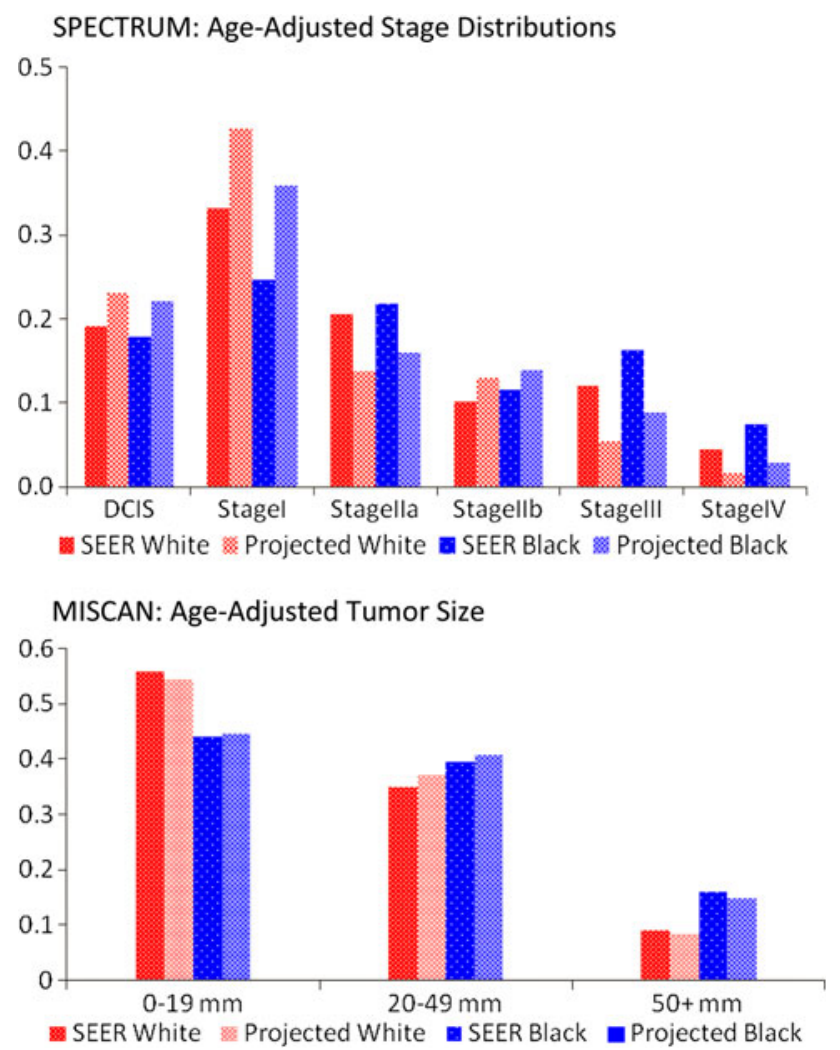

Fig. 2 Model predicted age-adjusted breast cancer stage distributions and tumor sizes by model and race versus observed SEER rates in 2007-2009 for US women age 25+

obesity had no direct impact on ER - tumors. There were insufficient data on obesity and HER2, so we assumed that obesity had no impact on HER2 distribution.

\section{Treatment}

Age-, year-, AJCC stage (or tumor size), and ER/HER2specific use of adjuvant hormonal and chemotherapy as disseminated from 1975 to 2000 was estimated from NCI's Patterns of Care studies [43, 44] and updated through 2010 using unpublished data from the National Comprehensive Cancer Network (NCCN) Outcomes Database. Compared to White women, Black women were $22 \%$ less likely to receive multi-agent chemotherapy and $10 \%($ age $<50)$ to $15 \%$ (age 50+) less likely to receive hormonal therapy. These Black-White differences were applied to the treatment dissemination curves. Obese and non-obese women had similar treatment patterns and obesity did not modify treatment in Blacks [45].

Women with ER+ invasive tumors receive hormonal treatment (tamoxifen from 1980 to 1999; tamoxifen if $<50$ years and anastrozole if $\geq 50$ years from 2000 to present) and non-hormonal treatment (CMF or anthracycline-based regimen from 1975 to 1999; anthracyclinebased plus taxanes from 2000 to present). Women with $\mathrm{ER}$ - invasive tumors receive non-hormonal therapy only. Women with DCIS and ER+ tumors receive hormonal therapy. Women with HER2+ tumors received trastuzumab beginning in 2005 [46].

Treatment effectiveness is based on RCTs [47-50]. Hormonal and chemotherapy regimens are equally effective in Black and White women [51]. We adjusted survival to reflect the fact that $\sim 30 \%$ of obese patients experience dose reductions and that $\mathrm{ER}$ - cases having dose-reductions experience decrements in survival of $55 \%[52,53]$.

Table 2 Projected breast cancer incidence in 2012 among women $25+$ by race, obesity, and model

\begin{tabular}{|c|c|c|c|c|c|c|}
\hline & \multicolumn{3}{|l|}{ White } & \multicolumn{3}{|l|}{ Black } \\
\hline & Obese & Non-obese & $\begin{array}{l}\text { All (weighted } \\
\text { sum of obese }+ \\
\text { non-obese) }\end{array}$ & Obese & Non-obese & $\begin{array}{l}\text { All (weighted } \\
\text { sum of obese }+ \\
\text { non-obese) }\end{array}$ \\
\hline \multicolumn{7}{|l|}{ SPECTRUM model } \\
\hline Age-adjusted incidence rate per $100,000^{\mathrm{a}}$ & 300.3 & 267.4 & 277.4 & 247.6 & 223.7 & 229.8 \\
\hline$\#$ of cases ${ }^{b}$ & 91,688 & 175,643 & 267,331 & 11,619 & 17,461 & 29,080 \\
\hline $\begin{array}{l}\text { Proportion of cases in the US population } \\
\text { attributable to obesity }{ }^{c}\end{array}$ & & & $4.5 \%$ & & & $3.6 \%$ \\
\hline \multicolumn{7}{|l|}{ MISCAN model } \\
\hline Age-adjusted incidence rate per $100,000^{\mathrm{a}}$ & 290.7 & 258.2 & 267.5 & 252.7 & 223.0 & 229.7 \\
\hline$\#$ of cases ${ }^{b}$ & 88,989 & 172,768 & 261,757 & 11,463 & 17,717 & 29,180 \\
\hline $\begin{array}{l}\text { Proportion of cases in the US population } \\
\text { attributable to obesity }{ }^{\mathrm{c}}\end{array}$ & & & $3.9 \%$ & & & $2.5 \%$ \\
\hline
\end{tabular}


No adjustment was applied for ER+ patients. We assumed that the impact of dose reductions was the same across all race groups and that obesity had no effects on treatment effectiveness of hormonal or trastuzumab therapy [9].

\section{Mortality}

SEER data from 1975 to 1979 were used to estimate breast cancer survival before screening and adjuvant treatment was available. Age-, race- and cohort-specific non-breast cancer mortality were calculated by subtracting breast cancer from all-cause mortality [54, 55]. The impact of obesity on non-breast cancer mortality was derived from NHANES-mortality linked data [8].

\section{Analysis}

The models simulate 1975-2020 age-adjusted breast cancer incidence and mortality rates for Black and White obese and non-obese women; adjustment is based on the standard US million population. This common referent population allows comparisons of results, as the age distributions of the population differ by race and obesity status. Overall, the US rates were estimated using a prevalence-weighted sum of the age-adjusted rates for the obese and non-obese women. Age-specific rates by race are used with the projected 2010 age-specific distribution of the respective populations [56] weighted by obesity prevalence to calculate numbers of cases and deaths. Additionally, we calculate the fraction of cases and deaths attributable to obesity. Finally, we investigate the effect of obesity on the difference in mortality between White and Black women, after considering the effect of race-differences in demography, incidence, natural history, screening use alone, adjuvant treatment use alone, and both screening and treatment. To this end, we sequentially substitute parameter values relating to these factors in the White version of the models with corresponding values from the Black version. In the final step, we add the prevalence of obesity among Blacks to the models. At each step, we compute the fraction of the mortality difference between White and Black women explained by each factor. The predicted breast cancer mortality rates at each step are also compared to the 3-year average of observed rates for Black women [3].

\section{Model validation}

The model validation has been described in previous publications [27, 28]. Results from two models provide implicit cross-validation, a range of plausible impacts of obesity, and a measure of uncertainty. Internal reliability was evaluated by combining incidence and mortality rates for obese and non-obese women in proportion to their ageand race-specific prevalence of obesity to verify that we reproduced overall population rates. Reliability of the model adaptations for obesity was also evaluated by comparing model outputs to observed SEER data.

\section{Results}

Observed incidence trends were accurately reproduced by both models. Mortality rates are reproduced for White women, and the shape of the curve is similar for Blacks, but lower than SEER (Fig. 1). The models mirror observed data showing that stage distribution (or tumor size) is more favorable in White than in Black women, but the models predict a slightly more favorable distribution for Blacks than actually observed (Fig. 2).

Impact of obesity on incidence

Obesity increases the incidence of breast cancer for both races, and the fraction of cases attributable to obesity is similar for Whites (3.9-4.5\%, across models) and Blacks (2.5-3.6\%) (Table 2; Fig. 3). The net impact of obesity on incidence is the result of opposing risk by age. The predicted incidence in obese women $<50$ years is $37-47 /$ 100,000 for Whites and 32-44/100,000 for Blacks. Among non-obese White and Black women $<50$ years, the corresponding rates are $47-60 / 100,000$ and $43-60 / 100,000$, respectively. Thus, elimination of obesity would actually increase the number of cases among women $<50$ years. For women aged 50+, obesity accounts for 5.5-6.4\% and 5.3-8.1\% of cases for White and Black women, respectively (data not shown).

Impact of obesity on breast cancer mortality

Obesity increases mortality rates for both race groups and accounts for $4.4-9.2 \%$ and 3.1-8.4 \% of the total deaths for Whites and Blacks, respectively, across models (Table 3; Fig. 4). This translates into 1,400-3,552 deaths in Whites and 148-412 deaths in Blacks that could be avoided each year if obesity were eliminated. Among women $<50$ years, obesity decreases death rates given the large decrease in incidence associated with its protective effects. For women age $50+$ of both race groups, obesity accounts for about $5.1-11.5 \%$ of the deaths in the overall US population.

Obesity and impact on Black-White differences in rates

The observed age-adjusted mortality rate was $33.9 / 100,000$ in Whites and 48.1/100,000 in Blacks from 2007 to 2009 
Fig. 3 Model predicted ageadjusted breast cancer incidence rates over time by model, race and obesity for US women age $25+$
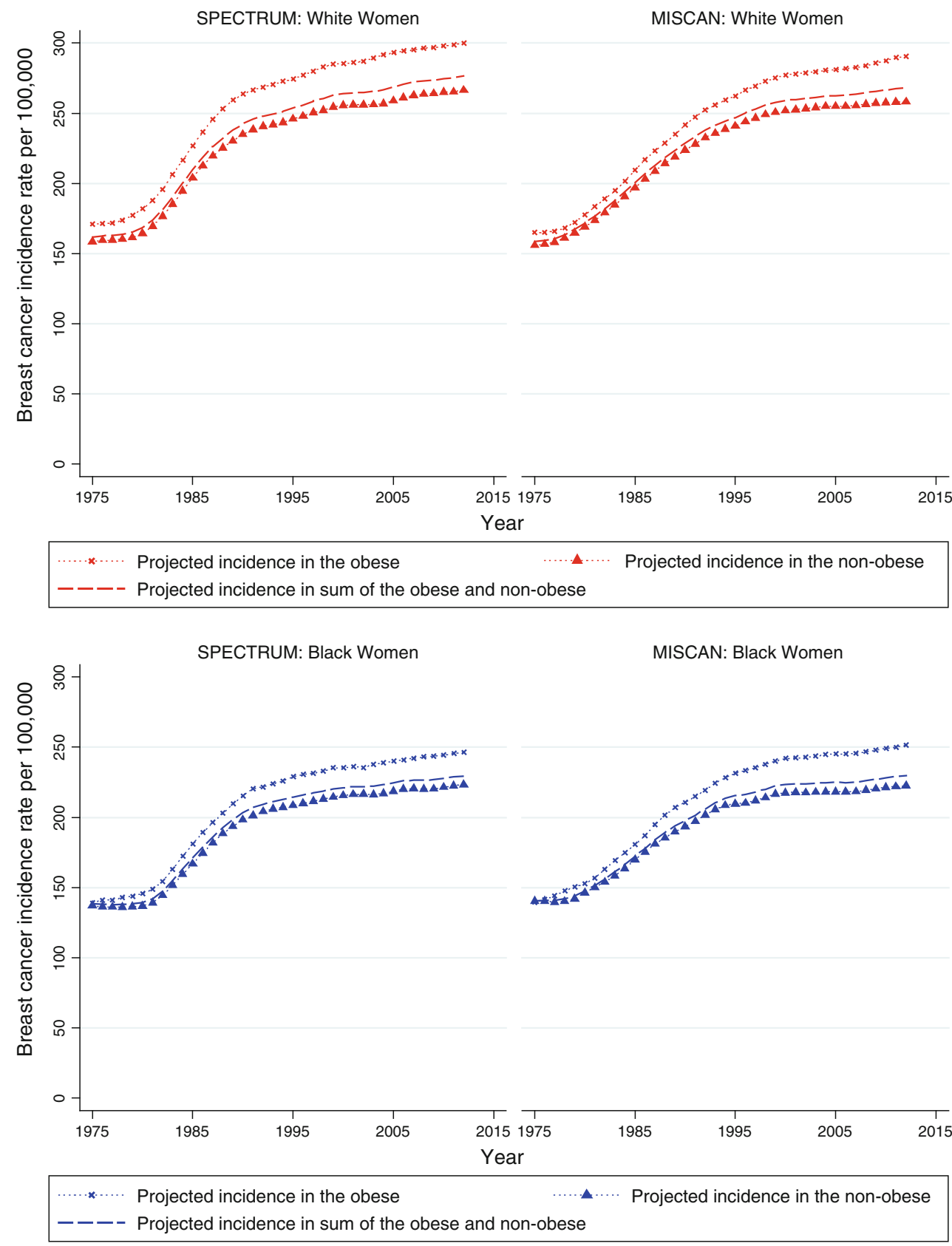

(latest years available). In Table 4, these values are compared to model predictions based on sequential replacement of parameter values in the White model by those from the Black model to test how much the higher prevalence of obesity in Black compared to White women affects the differences in mortality. As can be seen in Step 6, there is no net effect of race differences in obesity prevalence on mortality disparities. This result occurs because the higher prevalence of obesity among Black versus White women $<50$ years decreases cases and mortality, but increases these outcomes from ages 50 to 74 . As White women have a higher prevalence of obesity than Blacks after age 74, substituting the Black obesity prevalence (vs. White) decreases cases and deaths among the oldest women. Thus, differences in obesity prevalence do not account for the net age-adjusted mortality disparities between Blacks and Whites.

\section{Discussion}

This is the first study to use collaborative modeling to evaluate the impact of obesity on breast cancer incidence and mortality in White and Black women and to assess whether differences in obesity prevalence account for race disparities in mortality. We found that obesity accounts for 
Table 3 Projected breast cancer mortality in 2012 among women $25+$ by race, obesity, and model

\begin{tabular}{|c|c|c|c|c|c|c|}
\hline & \multicolumn{3}{|l|}{ White } & \multicolumn{3}{|l|}{ Black } \\
\hline & Obese & Non-obese & $\begin{array}{l}\text { All (weighted } \\
\text { sum of obese }+ \\
\text { non-obese) }\end{array}$ & Obese & Non-obese & $\begin{array}{l}\text { All (weighted } \\
\text { sum of obese }+ \\
\text { non-obese) }\end{array}$ \\
\hline \multicolumn{7}{|l|}{ SPECTRUM model } \\
\hline Age-adjusted mortality rate per $100,000^{\mathrm{a}}$ & 44.8 & 33.4 & 36.6 & 47.8 & 36.3 & 39.2 \\
\hline \# of deaths from breast cancer ${ }^{b}$ & 14,363 & 24,398 & 38,761 & 2,059 & 2,872 & 4,931 \\
\hline $\begin{array}{l}\text { Proportion of deaths in the US population } \\
\text { attributable to obesity }\end{array}$ & & & $9.2 \%$ & & & $8.4 \%$ \\
\hline \multicolumn{7}{|l|}{ MISCAN Model } \\
\hline Age-adjusted mortality rate per $100,000^{\mathrm{a}}$ & 35.8 & 30.9 & 32.2 & 41.1 & 36.0 & 37.3 \\
\hline \# of deaths from breast cancer ${ }^{\mathrm{b}}$ & 10,780 & 21,052 & 31,832 & 1,846 & 2,863 & 4,709 \\
\hline $\begin{array}{l}\text { Proportion of deaths in the US population } \\
\text { attributable to obesity }\end{array}$ & & & $4.4 \%$ & & & $3.1 \%$ \\
\hline
\end{tabular}

about 3-4\% of the cases and 3-9 \% of the deaths in both the race groups. Variations in obesity prevalence have no net effect on the mortality differences between Blacks and Whites.

The overall modest impact of obesity represents the balance of an increase in cases/deaths among a large number of post-menopausal women and a decrease among a smaller number of pre-menopausal women. The obesity attributable fraction of 5.3-8.1\% of cases among White and Black women 50 years and older we observed is similar to, but lower than prior US (8.9\%) [15] and UK estimates $(8.7 \%)$ because those included both overweight and obese women [57]. If obesity were eliminated we could avoid more than 12,000 cases among White women and 1,000 in Black women. There are few measures that can prevent so many breast cancer cases, except perhaps Tamoxifen use by high-risk women [58].

Obesity accounts for $<10 \%$ of breast cancer deaths across race groups. For colorectal cancer, elimination of obesity and other risk factors could reduce mortality by up to $16 \%$ [59]. Decreasing obesity has other important effects on health, such as reductions in risk of other cancers and heart disease, and could lower health care costs [21, 22, 60], making it an important public health target. However, while we can easily eliminate obesity in our model "laboratory," it is very difficult to treat in actual practice [61, 62]. Thus, the modest impact projected by our models may not be achievable, but provides an upper estimate of the impact of obesity control efforts on breast cancer.

The conclusions of both models were very similar, but MISCAN uses a cure model that generates lower breast cancer mortality rates than SPECTRUM that applies a hazard of breast cancer death over time [24, 27, 28]. MISCAN also projects less mortality difference between obese and non-obese women due to use of continuous tumor size rather than discrete tumor stages, yielding lower obesity attributable mortality fractions. These differences capture some uncertainty and provide users with a range of plausible results.

Obesity is a modest but potentially meaningful target in reducing the burden of breast cancer, but it does not appear to account for net racial differences in age-adjusted mortality. This conclusion is consistent with the recent finding of Lu et al. [63] that obesity did not affect breast cancer survival in Blacks ages 35-64, although it had a modest impact for Whites. Unfortunately, that study did not have information on treatment. Others have found that adjusting for obesity does not remove Black-White differences in deaths from breast cancer [64, 65].

Our approach builds on and extends prior modeling of the impact of obesity on cancer outcomes [59] by incorporating the impact of obesity on incidence, screening, and treatment parameters and examining results separately by race. Despite the strengths of our approach, there are some caveats that should be considered in evaluating the results. First, although weight can change over the life course [25], we modeled obesity as constant after onset given the unavailability of data to link changes in weight to the multiple input parameters. This may underestimate the impact of obesity because a transition from non-obese to obese around menopause, which is a common pattern, maximizes risk during both periods. Next, as in other models we consider two categories 
Fig. 4 Model projected ageadjusted breast cancer mortality rates over time by model, race and obesity in US women age $25+$

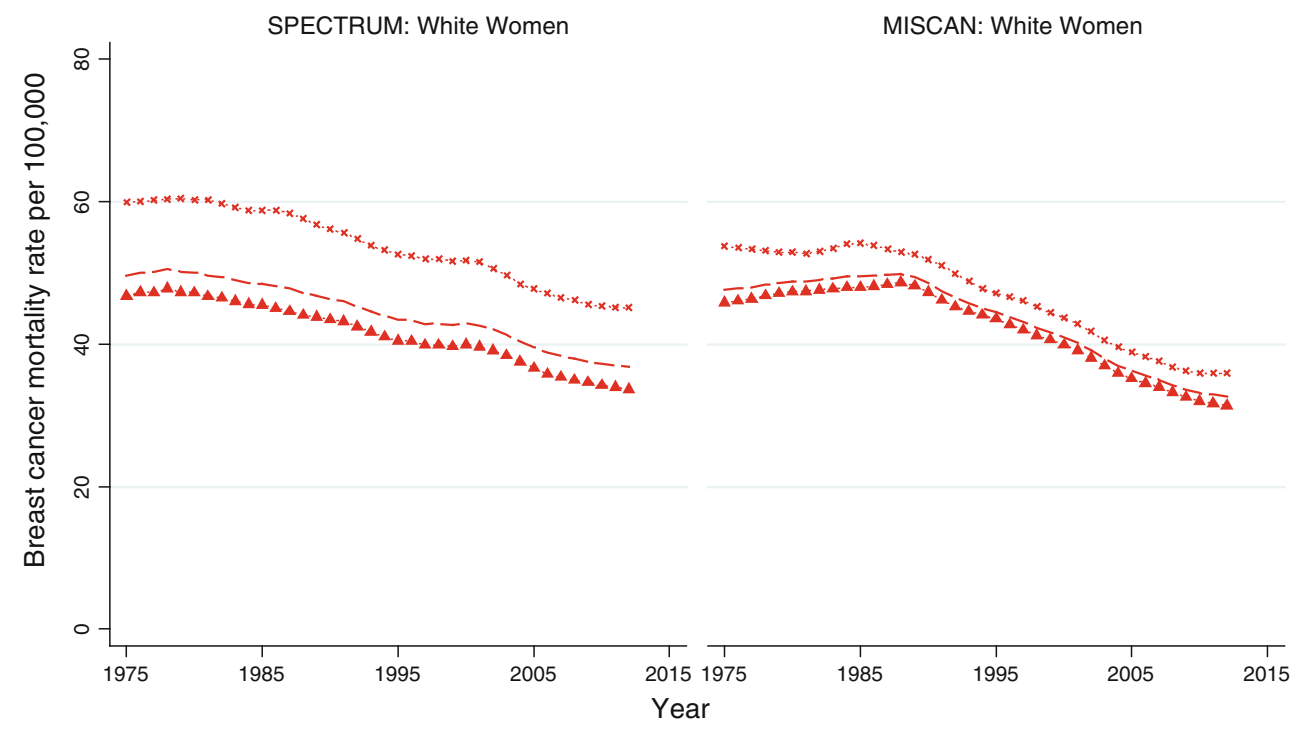

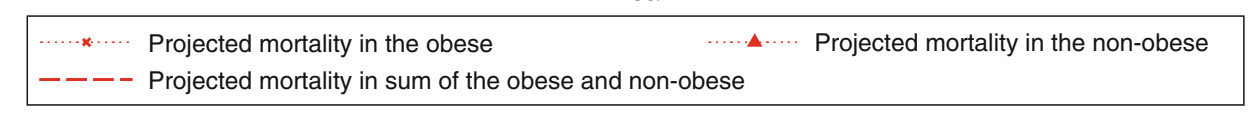

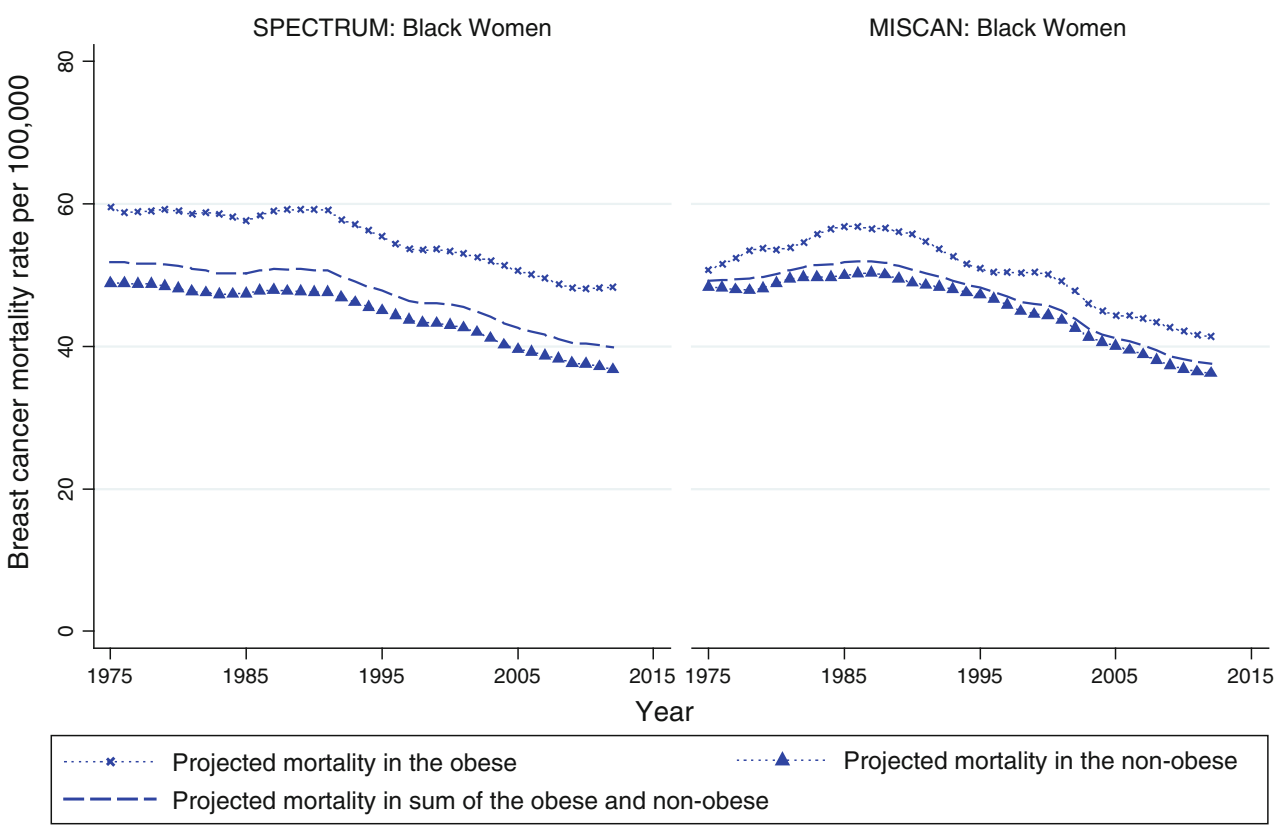

of obesity [59] but do not consider an overweight category or body fat distribution, given the paucity of consistent epidemiological data across parameters for a wider range of characterizations. Others have not found a difference in estimates of risk [66] or survival [67] based on different categorizations of weight and there is no consistent evidence to suggest that level of obesity interacts with race in its effects on cancer incidence [66]. Obesity is also the net result of diet and physical activity, and these factors may affect survival [68, 69]. However, it remains difficult to separately estimate the impact of these components (or their molecular correlates) [70-73] on the prevention, screening, treatment, and survival parameters included in the models. This is an important area for future research [25]. Until then, our results are useful as obesity is the most robustly related to breast cancer outcomes among measures of energy balance [66, 67].

Overall, these results represent the first comprehensive examination using comparative modeling of obesity and how it affects the entire breast cancer process from risk of disease to the type of disease at presentation and treatment impact in the context of competing mortality. The results indicate that obesity exerts a modest impact on breast cancer and does not explain net race disparities in outcome. However, obesity remains one of the few known modifiable risk factors for this and other diseases, increasing its relevance as a public health target for all women. 


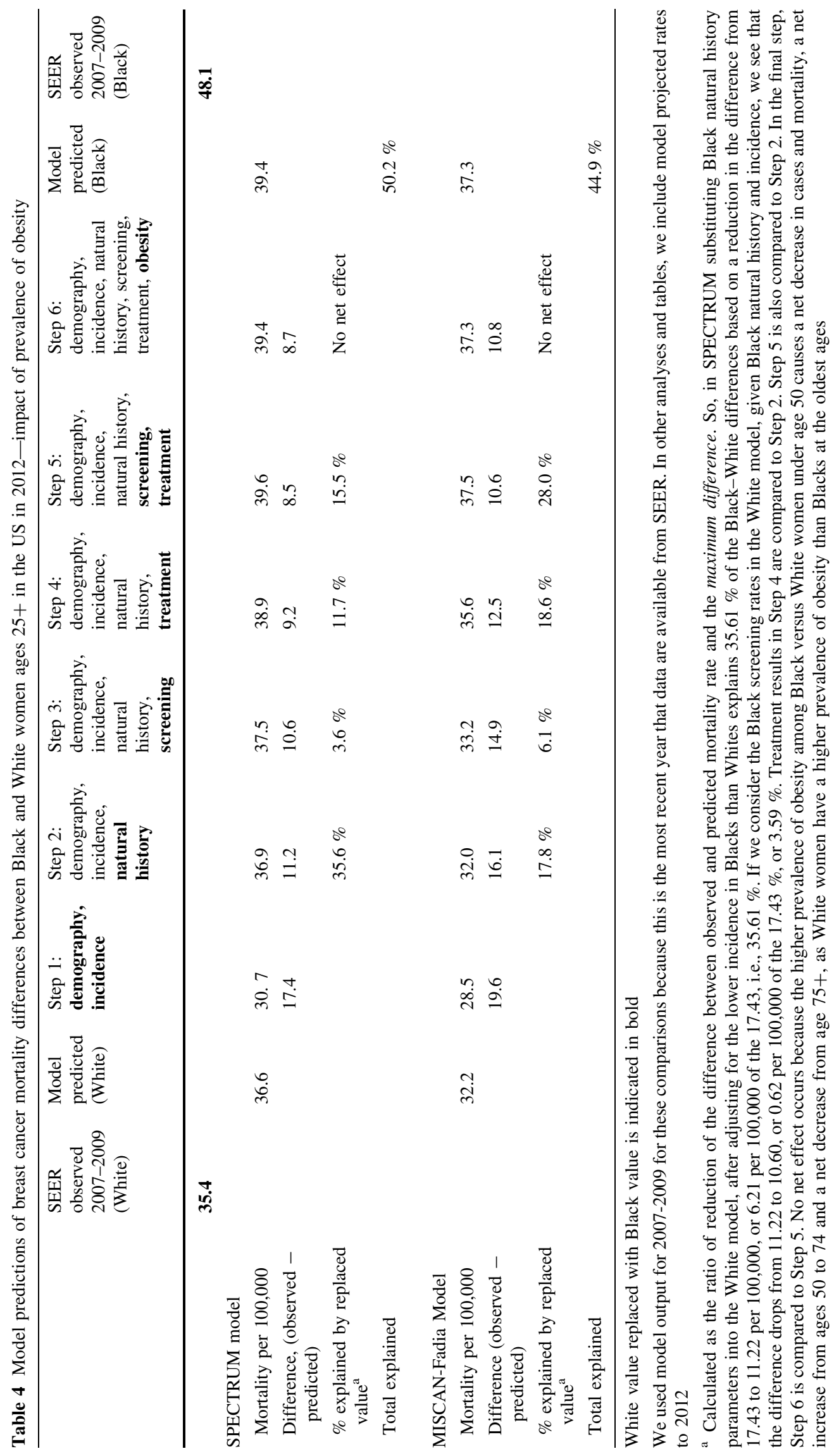


Acknowledgments We thank the Breast Cancer Surveillance Consortium (BCSC) investigators for the data they have provided for this study. A list of the BCSC investigators and procedures for requesting BCSC data for research purposes are provided at http://breastscreen ing.cancer.gov/. The collection of cancer data used in this study was supported in part by several state public health departments and cancer registries throughout the US. For a full description of these sources, please see http://www.breastscreening.cancer.gov/work/ack nowledgement.html. We thank the National Comprehensive Cancer Network investigators for use of their data on treatment dissemination. This work was supported by funding from the National Cancer Institute at the National Institutes of Health (NIH) (Grant Numbers U01CA088283, U01CA152958, and KO5CA96940 to JSM; Grant Number P01CA154292 to JSM and CBS; Grant Number R21CA 149996 to LLA; and Grant Number UO1CA152956 to DL). The views expressed in this article represent those of the authors and not the NIH. Breast Cancer Surveillance Consortium data collection and sharing was supported by the National Cancer Institute (Grant Numbers U01CA63740, U01CA86076, U01CA86082, U01CA63736, U01CA70013, U01CA69976, U01CA63731, U01CA70040, and HHSN261201100031C).

\section{Conflict of interest None.}

Open Access This article is distributed under the terms of the Creative Commons Attribution Noncommercial License which permits any noncommercial use, distribution, and reproduction in any medium, provided the original author(s) and the source are credited.

\section{References}

1. American Cancer Society. Breast Cancer Facts \& Figures 2011-2012. http://www.cancer.org/Research/CancerFactsFigures/BreastCancer FactsFigures/breast-cancer-facts-and-figures-2011-2012. Accessed May 1, 2012

2. Berry DA, Cronin KA, Plevritis SK, Fryback DG, Clarke L et al (2005) Cancer Intervention and Surveillance Modeling Network (CISNET) Collaborators. Effect of screening and adjuvant therapy on mortality from breast cancer. N Engl J Med 353(17):1784-1792

3. Surveillance, Epidemiology, and End Results (SEER) Program (www.seer.cancer.gov) SEER*Stat Database: Mortality-All COD, Aggregated with state, total US (1969-2009) < Katrina/ Rita Population Adjustment $>$-linked to county attributes-total US, 1969-2010 counties, National Cancer Institute, DCCPS. Accessed May 2012

4. Centers for Disease Control and Prevention (CDC): Behavioral Risk Factor Surveillance Systems survey data. Atlanta, Georgia: US Department of Health and Human Services, Centers for Disease Control and Prevention. www.cdc.gov/brfss. Accessed May 2012

5. Surveillance, Epidemiology, and End Results (SEER) Program (www.seer.cancer.gov) SEER*Stat Database: Incidence-SEER 9 Regs Research Data, Nov 2011 Sub, Vintage 2009 Pops (1973-2009) <Katrina/Rita Population Adjustment $>$-Linked To County Attributes-Total US, 1969-2010 Counties, National Cancer Institute, DCCPS. Accessed May 2012

6. Flegal K, Carroll M, Ogden C, Johnson C (2012) Prevalence of obesity and trends in the distribution of body mass index among US adults, 1999-2010. JAMA 307(5):491-497

7. NHANES, Centers for Disease Control and Prevention (CDC), National Center for Health Statistics (NCHS), National Health and Nutrition Examination Survey Data (2009). US Department of Health and Human Services, Centers for Disease Control and
Prevention, Hyattsville, Maryland. www/cdc/gov/nchs/nhanes.htm. Accessed May 2012

8. Wang YC, Graubard BI, Rosenberg MA, Kuntz KM, Zauber A, Kahle L, et al (2012) Derivation of background mortality by smoking and obesity in cancer stimulation models. Med Decis Making (in press)

9. Carmichael AR, Bates T (2004) Obesity and breast cancer: a review of the literature. Breast 13(2):85-92

10. van den Brandt PA, Spiegelman D, Yaun SS et al (2000) Pooled analysis of prospective cohort studies on height, weight, and breast cancer risk. Am J Epidemiol 152(6):514-527

11. Michels KB, Terry KL, Willett WC (2006) Longitudinal study on the role of body size in premenopausal breast cancer. Arch Intern Med 166(21):2395-2402

12. Yang XR, Chang-Claude J, Goode EL, Couch FJ, Nevanlinna H, Milne RL et al (2011) Associations of breast cancer risk factors with tumor subtypes: a pooled analysis from the Breast Cancer Association Consortium studies. J Natl Cancer Inst 103(3): 250-263

13. Canchola AJ, Anton-Culver H, Bernstein L, Clarke CA, Henderson K, Ma $\mathrm{H}$ et al (2012) Body size and the risk of postmenopausal breast cancer subtypes in the California Teachers Study cohort. Cancer Causes Control 23(3):473-485

14. Suzuki R, Orsini N, Saji S, Key TJ, Wolk A (2009) Body weight and incidence of breast cancer defined by estrogen and progesterone receptor status - a meta-analysis. Int J Cancer 124(3):698-712

15. Kerlikowske K, Walker R, Miglioretti DL, Desai A, BallardBarbash R, Buist DS (2008) Obesity, mammography use and accuracy, and advanced breast cancer risk. J Natl Cancer Inst 100(23):1724-1733

16. Hahn KM, Bondy ML, Selvan M et al (2007) Factors associated with advanced disease stage at diagnosis in a population-based study of patients with newly diagnosed breast cancer. Am J Epidemiol 166(9):1035-1044

17. Cui Y, Whiteman M, Langenberg P, Sexton M, Tkaczuk K, Flaws J (2004) Can obesity explain the racial difference in stage of breast cancer at diagnosis between black and white women? J Womens Health Gend Based Med 11(5):527-536

18. Cui Y, Whiteman M, Flaws J, Langenberg P, Tkaczuk K, Bush T et al (2002) Body mass and stage of breast cancer at diagnosis. Int J Cancer 98:279-283

19. Rosner GL, Hargis JB, Hollis DR, Budman DR, Weiss RB, Henderson IC et al (1996) Relationship between toxicity and obesity in women receiving adjuvant chemotherapy for breast cancer: results from cancer and leukemia group B study 8541 . J Clin Oncol 14(11):3000-3008

20. Colleoni M, Li S, Gelber RD, Price KN, Coates AS, CastiglioneGertsch $M$ et al (2005) Relation between chemotherapy dose, oestrogen receptor expression, and body-mass index. Lancet 366(9491): 1108-1110

21. Peeters A, Barendregt JJ, Willekens F, Mackenbach JP, Al Mamum A, Bonneux L (2003) Obesity in adulthood and its consequences for life expectancy: a life-table analysis. Ann Intern Med 138(1):24-32

22. Flegal KM, Graubard BI, Williamson DF, Gail MH (2007) Cause-specific excess deaths associated with underweight, overweight, and obesity. JAMA 298(17):2028-2037

23. Kumanyika SK, Parker L, Sim LJ (2010) Bridging the evidence gap in obesity prevention: a framework to inform decision making. Institute of Medicine, The National Academies Press, Washington, DC

24. van Ravesteyn NT, Schechter CB, Near AM, Heijnsdijk EA, Stoto MA, Draisma G et al (2011) Race-specific impact of natural history, mammography screening, and adjuvant treatment on breast cancer mortality rates in the United States. Epidemiol Biomarkers Prev 20(1):112-122 
25. Levy DT, Mabry PL, Wang YC, Gortmaker S, Huang TT, Marsh $T$ et al (2011) Simulation models of obesity: a review of the literature and implications for research and policy. Obes Rev 12(5):378-394

26. CISNET Cancer Intervention and Surveillance Modeling Network. http://cisnet.cancer.gov. Accessed May 2012

27. Tan SY, van Oortmarssen GJ, de Koning HJ, Boer R, Habbema JD (2006) The MISCAN-Fadia continuous tumor growth model for breast cancer. J Natl Cancer Inst Monogr 36:56-65

28. Mandelblatt J, Schechter CB, Lawrence W, Yi B, Cullen J (2006) The SPECTRUM population model of the impact of screening and treatment on US breast cancer trends from 1975 to 2000: principles and practice of the model methods. J Natl Cancer Inst Monogr 36:47-55

29. Mandelblatt JS, Cronin KA, Bailey S, Berry DA, de Koning HJ, Draisma $G$ et al (2009) Effects of mammography screening under different screening schedules: model estimates of potential benefits and harms. Ann Intern Med 151(10):738-747

30. Carter SB, Gartner SS, Haines MR et al (2006) Historical statistics of the united states, volume one: population. Cambridge University Press, New York

31. Holford TR, Cronin KA, Mariotto AB, Feuer EJ (2006) Changing patterns in breast cancer incidence trends. J Natl Cancer Inst Monogr 36:19-25

32. Ravdin PM, Cronin KA, Howlader N et al (2007) The decrease in breast-cancer incidence in 2003 in the United States. N Engl J Med 356(16):1670-1674

33. Kelsey JL (1993) Breast cancer epidemiology: summary and future directions. Epidemiol Rev 15(1):256-263

34. Cronin KA, Yu B, Krapcho M, Miglioretti DL, Fay MP, Izmirlian $\mathrm{G}$ et al (2005) Modeling the dissemination of mammography in the United States. Cancer Causes Control 16(6):701-712

35. Cronin KA, Mariotto AB, Clarke LD, Feuer EJ (2006) Additional common inputs for analyzing impact of adjuvant therapy and mammography on US mortality. J Natl Cancer Inst Monogr $36: 26-29$

36. Cronin KA, Miglioretti DL, Krapcho M, Yu B, Geller BM, Carney PA et al (2009) Bias associated with self-report of prior screening mammography. Cancer Epidemiol Biomarkers Prev 18(6):1699-1705

37. Cronin KA, Miglioretti DL, Krapcho M, Yu B, Geller BM, Carney PA, et al CEBP focus on cancer surveillance: bias associated with self-report of prior screening mammographyappendix: modeling mammography screening usage by race and ethnicity. Technical Report \#2012-02. http://surveillance.cancer. gov/reports/. Accessed January 2010

38. Zhu K, Wu H, Jatoi I, Potter J, Shriver C (2006) Body mass index and use of mammography screening in the United States. Prev Med 42:381-385

39. Breast Cancer Surveillance Consortium. Performance Measures for 3,884,059 Screening Mammography Examinations from 1996 to 2007 by Age — based on BCSC data as of 2008. http://breastsc reening.cancer.gov/data/performance/screening/2008/perf_age.html. Accessed April 2008

40. Altekruse SF, Kosary CL, Krapcho M, Neyman N, Aminou R, Waldron W. SEER Cancer Statistics Review, 1975-2007, National Cancer Institute. Bethesda, MD. http://seer.cancer.gov/ csr/1975-2007/ based on November 2009 SEER data submission, posted to the SEER web site, 2010. Accessed January 2011

41. Cust AE, Stocks T, Lukanova A, Lundin E, Hallmans G, Kaaks R et al (2009) The influence of overweight and insulin resistance on breast cancer risk and tumour stage at diagnosis: a prospective study. Breast Cancer Res Treat 113(3):567-576

42. Bekele BN, Nieto-Barajas LE, Munsell MF. Analysis of partially incomplete tables of breast cancer patients' characteristics with an ordinal variable. J Stat Theory Practice (accepted). To appear in December 2012

43. Mariotto AB, Feuer EJ, Harlan LC, Abrams J (2006) Dissemination of adjuvant multiagent chemotherapy and tamoxifen for breast cancer in the United States using estrogen receptor information: 1975-1999. J Natl Cancer Inst Monogr 36:7-15

44. Mariotto A, Feuer EJ, Harlan LC, Wun LM, Johnson KA, Abrams $\mathbf{J}$ (2002) Trends in use of adjuvant multi-agent chemotherapy and tamoxifen for breast cancer in the United States: 1975-1999. J Natl Cancer Inst 94(21):1626-1634

45. Brewster AM, Etzel C, Zhou R, Wong Y, Edge S, Blayney DW et al (2011) The impact of obesity on receipt of adjuvant chemotherapy for breast cancer in the National Comprehensive Cancer Network (NCCN) centers. Breast Cancer Res Treat 130(3):897-904

46. National Comprehensive Cancer Network. NCCN Clinical Practice Guidelines in oncology v.2 (2008). www.nccn.org/profes sional/physician_gls/f_guidelines.asp. Accessed September 2009

47. Early Breast Cancer Trialists' Collaborative Group (EBCTCG) (2005) Effects of chemotherapy and hormonal therapy for early breast cancer on recurrence and 15-year survival: an overview of the randomised trials. Lancet 365(9472):1687-1717

48. Early Breast Cancer Trialists' Collaborative Group (EBCTCG) (1998) Polychemotherapy for early breast cancer: an overview of the randomised trials. Lancet 352(9132):930-942

49. Early Breast Cancer Trialists' Collaborative Group (EBCTCG) (1998) Tamoxifen for early breast cancer: an overview of the randomised trials. Lancet 351(9114):1451-1467

50. Clarke M, Coates AS, Darby SC, Davies C, Gelber RD, Godwin J et al (2008) Adjuvant chemotherapy in oestrogen-receptor-poor breast cancer: patient-level meta-analysis of randomised trials. Lancet 371(9606):29-40

51. Dignam JJ (2001) Efficacy of systemic adjuvant therapy for breast cancer in African-American and Caucasian women. J Natl Cancer Inst Monogr 30:36-43

52. Griggs JJ, Sorbero ME, Lyman GH (2005) Undertreatment of obese women receiving breast cancer chemotherapy. Arch Intern Med 165(11):1267-1273

53. Griggs JJ, Culakova E, Sorbero ME et al (2007) Effect of patient socioeconomic status and body mass index on the quality of breast cancer adjuvant chemotherapy. J Clin Oncol 25(3):277-284

54. National Center for Health Statistics (2000) United States, 2000 Public Health Service, Hyattsville. http://www.cdc.gov/nchs/prod ucts/life_tables.htm. Accessed May 2012

55. Human Mortality Database (2011). Centers for Disease Control and Prevention, Publications and Information Products, Life Tables. http://www.mortality.org. Accessed August 2011

56. Projected population by single year of age, sex, race, and hispanic origin for the United States: July 1, 2000 to July 1, 2050. Released 2008. http://www.census.gov/population/www/project ions/downloadableflies.html. Accessed May 2012

57. Parkin DM, Boyd L, Walker LC (2011) The fraction of cancer attributable to lifestyle and environmental factors in the UK in 2010. Br J Cancer 105(Suppl 2):S77-S81

58. Fisher B, Costantino JP, Wickerham DL, Redmond CK, Kavanah M, Cronin WM et al (1998) Tamoxifen for prevention of breast cancer: report of the National Surgical Adjuvant Breast and Bowel Project P-1 Study. J Natl Cancer Inst 90(18):1371-1388

59. Vogelaar I, Van Ballegooijen M, Schrag D, Boer R, Winawer SJ, Habbema JD et al (2006) How much can current interventions reduce colorectal cancer mortality in the US? Mortality projections for scenarios of risk-factor modification, screening, and treatment. Cancer 107(7):1624-1633

60. Finkelstein EA, Trogdon JG, Cohen JW, Dietz W (2009) Annual medical spending attributable to obesity: payer-and service-specific estimates. Health Aff (Millwood) 28(5):w822-w831 
61. National Institutes of Health (1998) Clinical guidelines on the identification, evaluation, and treatment of overweight and obesity in adults-the evidence report. Obes Res 6(Suppl 2):51S-209S

62. Fogelholm M, Kukkonen-Harjula K, Nenonen A, Pasanen M (2000) Effects of walking training on weight maintenance after a very-low-energy diet in premenopausal obese women: a randomized controlled trial. Arch Intern Med 160(14):2177-2184

63. Lu Y, Ma H, Malone KE, Norman SA, Sullivan-Halley J, Strom BL et al (2011) Obesity and survival among black women and white women 35 to 64 years of age at diagnosis with invasive breast cancer. J Clin Oncol 29(25):3358-3365

64. McCullough ML, Feigelson HS, Diver WR, Patel AV, Thun MJ, Calle EE (2005) Risk factors for fatal breast cancer in AfricanAmerican women and White women in a large US prospective cohort. Am J Epidemiol 162(8):734-742

65. Conroy SM, Maskarinec G, Wilkens LR, White KK, Henderson BE, Kolonel LN (2011) Obesity and breast cancer survival in ethnically diverse postmenopausal women: the Multiethnic Cohort Study. Breast Cancer Res Treat 129(2):565-574

66. Sexton KR, Franzini L, Day RS, Brewster A, Vernon SW, Bondy ML (2011) A review of body size and breast cancer risk in Hispanic and African American women. Cancer 117(23):5271-5281

67. Protani M, Coory M, Martin JH (2010) Effect of obesity on survival of women with breast cancer: systematic review and meta-analysis. Breast Cancer Res Treat 123(3):627-635

68. Beasley JM, Kwan ML, Chen WY, Weltzien EK, Kroenke CH, Lu W et al (2012) Meeting the physical activity guidelines and survival after breast cancer: findings from the after breast cancer pooling project. Breast Cancer Res Treat 131(2):637-643
69. Kwan ML, Chen WY, Kroenke CH, Weltzien EK, Beasley JM, Nechuta SJ et al (2012) Pre-diagnosis body mass index and survival after breast cancer in the After Breast Cancer Pooling Project. Breast Cancer Res Treat 132(2):729-739

70. Esfahlan RJ, Zarghami N, Esfahlan AJ, Mollazadeh M, Nejati K, Nasiri M (2011) The possible impact of obesity on androgen, progesterone and estrogen receptor (ER-alpha and ER-beta) gene expression in breast cancer patients. Breast Cancer (Auckl) 5: 227-237

71. Chlebowski RT (2012) Obesity and breast cancer outcome: adding to the evidence. J Clin Oncol 30(2):126-128

72. Goodwin PJ, Ennis M, Pritchard KI, Trudeau ME, Koo J, Taylor SK et al (2012) Insulin- and obesity-related variables in earlystage breast cancer: correlations and time course of prognostic associations. J Clin Oncol 30(2):164-171

73. Gu JW, Young E, Patterson SG, Makey KL, Wells J, Huang M et al (2011) Postmenopausal obesity promotes tumor angiogenesis and breast cancer progression in mice. Cancer Biol Ther 11(10):910-917

74. Wang Y, Beydoun MA (2007) The obesity epidemic in the United States-gender, age, socioeconomic, racial/ethnic, and geographic characteristics: a systematic review and metaregression analysis. Epidemiol Rev 29:6-28

75. Wang YC, Colditz GA, Kuntz KM (2007) Forecasting the obesity epidemic in the aging US population. Obesity (Silver Spring) 15(11):2855-2865

76. Lee S, Zelen M (2006) A stochastic model for predicting the mortality of breast cancer. J Natl Cancer Inst Monogr 36:79-86 